Article

\title{
Effects of Wound-Healing Management on Potato Post-Harvest Storability
}

\author{
Yi Wang *, Mack R. Naber and Trevor W. Crosby \\ Department of Horticulture, University of Wisconsin-Madison, 1575 Linden Drive, Madison, WI 53706, USA; \\ mrnaber@wisc.edu (M.R.N.); twcrosby@wisc.edu (T.W.C.) \\ * Correspondence: wang52@wisc.edu; Tel.: +01-608-265-4781
}

Received: 4 March 2020; Accepted: 31 March 2020; Published: 3 April 2020

\begin{abstract}
A critical step in profitable post-harvest potato storage management is to cure tubers at appropriate temperatures long enough for rapid wound-healing to prevent disease and defect development, but not too long to jeopardize storage quality. A two-year storage study was conducted in macro-storage totes at the University of Wisconsin Hancock storage research facility to evaluate the effects of higher wound-healing temperatures $\left(15.6^{\circ} \mathrm{C}, 18.3^{\circ} \mathrm{C}\right)$ imposed for different durations, and compare them to the U.S. potato industry's standard practice $\left(12.8^{\circ} \mathrm{C}\right)$, on weight loss and frying quality of multiple processing potato varieties during long-term storage. It was found that in the experimental setting of this study, warmer wound-healing temperatures resulted in (1) less weight loss, particularly during the early storage season across varieties; (2) ameliorated senescent sweetening of the Snowden variety; (3) improved fry quality of the Russet Burbank variety; (4) and no apparent disease spread during long-term storage if tubers were harvested healthy out of fields. Overall, no significant difference was found between $15.6^{\circ} \mathrm{C}$ and $18.3^{\circ} \mathrm{C}$ regarding their treatment effects. Our conclusion is that compared to the current standard practice, higher wound-healing temperatures may have the potential benefits of improving potato storage quality while reducing the economic penalty associated with weight loss for specific varieties, but tubers should be healthy at harvest in order to gain the benefits. Further research is needed to test if those benefits of higher wound-healing temperatures hold true in large-scale commercial storage facilities.
\end{abstract}

Keywords: potatoes; post-harvest storage; wound healing; temperature; weight loss; fry quality

\section{Introduction}

Storage is a vital process to ensure year-round supplies for the fresh market and processing potato (Solanum tuberosum L.) industries. A key step of successful potato storage management is appropriate wound healing, the first two to three weeks after harvest during which the potatoes are held at an elevated temperature before final holding temperature is reached [1]. Wound healing can impact potato tuber long-term storability and can be detrimental to end product quality $[2,3]$.

The outmost layer of a potato tuber is the periderm that protects potatoes from weight loss and pathogen attack [4]. The periderm is subject to wounding, which is common during potato harvest and handling. Wounds can be in the form of cuts, punctures, abrasions, broken knobs, shatter-bruised areas, or any area that has a break in the periderm [5]. The purpose of wound healing is for the tubers to quickly repair periderm damage under a warm and high-humidity environment. Rapid development of wound periderm is critical to minimize subsequent weight loss or disease spread $[6,7]$. Wound periderm formation is initiated when cell division increases and suberin deposition occurs in response to wounding [8-10]. The primary role of suberin is to serve as a barrier to both water loss and microbial infection [11]. Suberin can auto-fluoresce under ultra-violet light [12,13]. This trait can 
be used as an approach to evaluate the progression of suberization to make informed decisions on wound-healing management during the early storage stage [14].

The rate of wound healing depends on several factors including type of wounds, variety, and storage conditions [14]. Deep or angled wounds are more difficult to cure because they are hidden from the ventilation air, which can decrease the tubers' ability to quickly dry off the moisture and stop disease spread [5]; meanwhile the agent (rocks, sharp edge on equipment, etc.) that causes the periderm damage can inoculate the wounding area. Varieties can respond differently to wound healing-some might be faster or slower than others-depending on the varietal susceptibility to rotting diseases such as bacterial soft rot (Pectobacterium spp.), pink rot (Phytophora erythroseptica), Pythium leak (Pythium spp.), and Fusarium dry rot (Fusarium spp.). The development of the wound periderm and primary suberization is favored by high relative humidity at $95 \%-98 \%$, the presence of oxygen $[15,16]$, and temperature at $10.0^{\circ} \mathrm{C}$ to $15.6{ }^{\circ} \mathrm{C}$ [17]. Suberization is faster under warmer temperature and inhibited under cooler temperature [18].

Current standard industry practice for potato wound healing in the U.S. is to store freshly harvested potatoes for two to three weeks in the temperature range of 10.0 to $12.8^{\circ} \mathrm{C}$ under high humidity $(95 \%-98 \%)$ and good airflow $[14,19]$. High humidity is needed to reduce water loss from the tuber before the wound-healing process concludes [20]. Maintaining high relative humidity can prevent early season tuber dehydration and help control total tuber shrinkage during the entire storage season. Good airflow in the storage pile can prevent moisture condensation on the tuber surface and subsequent oxygen deprivation, both of which enhance disease spread, as well as remove water from decaying tubers and carbon dioxide from tuber respiration [21]. Temperatures below $10.0^{\circ} \mathrm{C}$ reduce the rate of wound healing, and thus require a longer curing duration that allows diseases the chance to infect; temperatures above $15.6^{\circ} \mathrm{C}$ may be beneficial in the formation of the wound periderm, but greater disease development can be a negative consequence [19]. It is critical to avoid keeping the tubers warm for an extended period of time because most rot organisms spread much faster at warm temperatures [22]. Therefore the best management practice will be to cure potatoes at temperatures just long enough to allow for rapid wound healing, but not too long to have an impact on weight loss, disease development, or other quality characteristics like shelf-life for fresh market varieties and frying quality for processing varieties [23].

The objective of this study is to compare effects of higher wound-healing temperatures imposed for different durations, to the U.S. potato industry's standard practice, on weight loss and frying quality of multiple processing potato varieties during long-term storage.

\section{Materials and Methods}

\subsection{Agronomic Practices}

Studies were conducted in 2017 and 2018 at the University of Wisconsin (UW) Hancock Potato and Vegetable Storage Research Facility (HPSRF, latitude: $44^{\circ} 8^{\prime} 23^{\prime \prime} \mathrm{N}$; longitude: $89^{\circ} 31^{\prime} 23^{\prime \prime}$ ). Russet Burbank (dual purpose for fresh market consumption and for French fry processing, No. 1 potato variety in the U.S.), Snowden (chipping variety, No. 3 public chipping variety in the U.S.), Hodag (chipping variety, a new variety released by the UW potato breeding program) were tested in both years. Lamoka (chipping variety, No. 1 public chipping variety in the U.S.) was tested only in 2018. In 2017, potatoes were donated from a commercial farm that was within $5 \mathrm{~km}$ of HPSRF. Snowden was harvested first, Russet Burbank and Hodag were harvested two days later, and all harvesting decisions were made by the farm owner. All potatoes were produced under standard production practices specific to the donor farm. In 2018, potatoes were grown at the UW Hancock Agricultural Research Station (same location as HPSRF, elevation: $328 \mathrm{~m}$ ). The soil type was Plainfield loamy sand (sandy, mixed, mesic, Typic Udipsamments). Planting in each year occurred between the last week of April and the first week of May, and harvest was in the last week of September. In 2018, certified potato seed tubers were machine cut to an average seed piece size of $57-71 \mathrm{~g}$, and planted approximately $16 \mathrm{~cm}$ 
deep, $30 \mathrm{~cm}$ in-row and $91 \mathrm{~cm}$ between-row spacing. Irrigation, fertility, and pesticide applications were based on the best management practices recommended by UW [24]. Target N, P, and K were 340,72 , and $325 \mathrm{~kg} \mathrm{ha}^{-1}$, respectively. A weather station (Campbell Scientific, Logan, UT) was located within $500 \mathrm{~m}$ of experimental plots recording precipitation, maximum and minimum soil temperature, solar radiation, relative humidity, and wind speed on a daily basis. Vine killing was conducted in early September (14 days before harvest) of each year to promote skin set on the tubers.

\subsection{Storage Practices}

At harvest, rocks, soil debris and clods, and foreign materials were hand removed from the tubers. Pulp temperatures of the tubers at harvest ranged between $12.2^{\circ} \mathrm{C}$ and $15.6{ }^{\circ} \mathrm{C}$. About $1350 \mathrm{~kg}$ of each variety was machine harvested and evenly put into three large plastic storage totes $(114 \mathrm{~cm}(\mathrm{~L}) \times 123$ $\mathrm{cm}(\mathrm{W}) \times 88 \mathrm{~cm}(\mathrm{H})$, Capacity $450 \mathrm{~kg}$, Figure 1) (model 34-S, MacroPlastics Inc., Fairfield, CA), which were placed on top of each other to simulate commercial industry practice. Gaps between the totes were tightly sealed by plastic wraps to ensure consistent airflow within the totes. The totes were then held under each of the three wound-healing treatments. Under each treatment, from top to bottom the order of the totes was Snowden, Hodag and Russet Burbank in 2017 and Snowden, Lamoka, Hodag and Russet Burbank in 2018. In each tote three replications of $4.5 \mathrm{~kg}$ of healthy potatoes were randomly selected and placed into polypropylene mesh bags, which were then placed on the top of the storage pile within the tote.

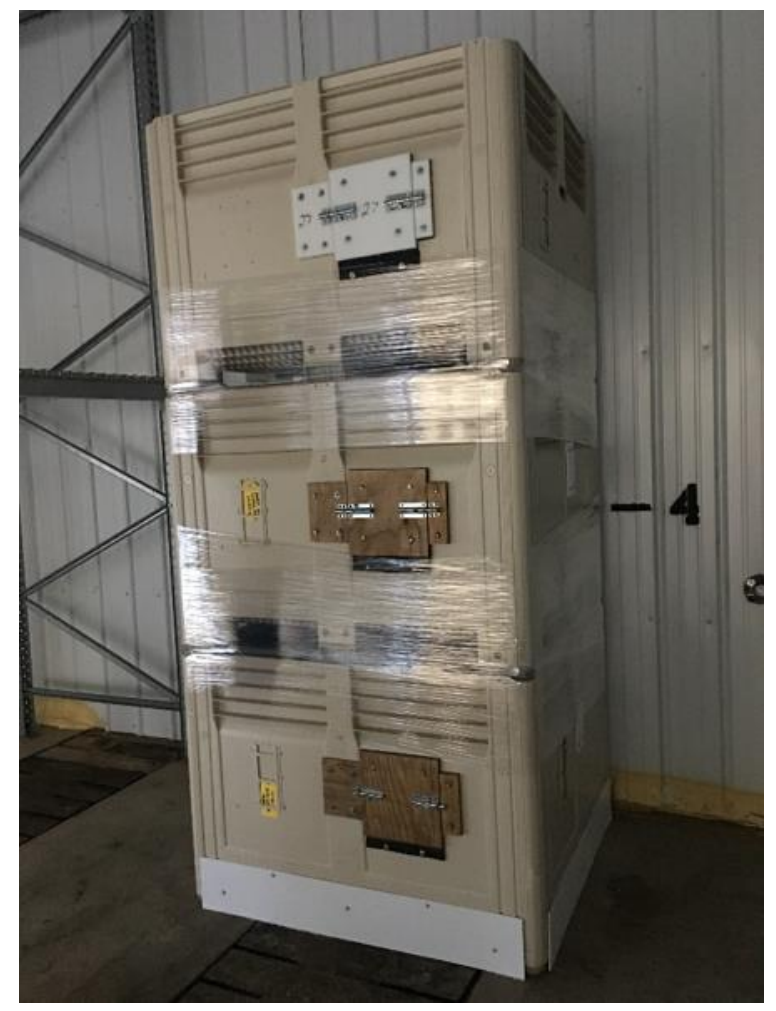

Figure 1. Large plastic totes used for holding potatoes for each variety/treatment were placed top of each other during storage.

Relative humidity was maintained above $95 \%$ for all treatments throughout the entire duration of storage via a plenum humida-cell with supplemental spray nozzles as a back-up in the event of the humida-cell failing. The sprout inhibitor, isopropyl N-(3-chlorophenyl)carbamate (CIPC, Decco Chemical, at $78.6 \%$ a.i.), was applied to all totes as a thermal aerosol at a rate of $22 \mathrm{mg}$ $\mathrm{Kg}^{-1}$ approximately 30 days after harvest. Sprouting was completely controlled in the 2017 storage 
season. In 2018, peeping $(<1 \mathrm{~mm})$ was observed on tubers starting from the 6th month in storage. Three wound-healing treatments were:

1. wound healing at $12.8^{\circ} \mathrm{C}$ for 30 days, applied CIPC, and then ramped down to holding temperature $\left(8.9^{\circ} \mathrm{C}\right)$ at a rate of $0.3^{\circ} \mathrm{C} /$ day, and this is the standard practice currently adopted by growers;

2. wound healing at $15.6^{\circ} \mathrm{C}$ for 10 days, lowered down to $12.8^{\circ} \mathrm{C}$ at a rate of $0.6^{\circ} \mathrm{C} /$ day, applied $\mathrm{CIPC}$, and then ramped down to holding temperature $\left(8.9^{\circ} \mathrm{C}\right)$ at a rate of $0.3^{\circ} \mathrm{C} /$ day;

3. wound healing at $18.3^{\circ} \mathrm{C}$ for 5 days, lowered down to $12.8^{\circ} \mathrm{C}$ at a rate of $0.6^{\circ} \mathrm{C} /$ day, applied $\mathrm{CIPC}$, and then ramped down to holding temperature $\left(8.9^{\circ} \mathrm{C}\right)$ at a rate of $0.3^{\circ} \mathrm{C} /$ day.

Post-harvest quality measurements, including percent fresh weight loss, fry color of all varieties, sugar end defect of Russet Burbank, sucrose and glucose content, and disease incidence of bacterial soft rot, Pythium leak and Fusarium dry rot were assessed at 1 month intervals for 8 months starting from harvest. There were 9 sampling points in each storage season. To avoid the confounding effects of planting date-induced differences in tuber size distribution on storability and processing quality, only the 171 to $284 \mathrm{~g}$ tubers (marketable size) were retained for use in weight loss, processing quality, and disease evaluation.

\subsection{Weight Loss}

Weight loss data was collected on the three replications of $4.5 \mathrm{~kg}$ healthy tubers contained in mesh bags within each tote. Tuber sample fresh weights were recorded prior to placing in storage, and then recorded in each month until late June of the following year. Weight loss was reported on a percent fresh weight basis. Monthly weight loss was calculated as (weight in the previous month-weight in the current month)/weight in the previous month. Total weight loss was summed up across the eight months in each storage season.

\subsection{Assessment of Fry Color}

For Russet Burbank, one fried plank $(3.0 \mathrm{~cm} \times 0.8 \mathrm{~cm} \times$ length of tuber) from each of 10-tuber samples, with three replications from each tote, was used for fry color determination within one week of harvest and then monthly in storage. Planks were fried in canola oil at $191^{\circ} \mathrm{C}$ for $3.5 \mathrm{~min}$ and blotted dry to remove extra oil. Fry color was determined within the first 3 min after frying using a model 577 Photovolt Reflectometer (model 577, Photovolt Instruments Inc., Minneapolis, MN, USA). As per the manufacturer's recommendation, a green filter was used and calibrated, using a black-cavity standard as $0.0 \%$ reflectance and a white plaque as $99.9 \%$ reflectance. Measurements were taken on the bud and stem ends of each plank. A relationship between the United States Department of Agriculture (USDA) standard fry color and the photovolt reflectance was previously established [25]. A USDA fry color rating 1 was equal to a 44.0 or greater reflectance reading, a USDA 2 rating was less than 44.0 to 35.0 reflectance reading, a USDA 3 rating was less than 35.0 to 26.0 reflectance reading, and a USDA 4 rating was less than 26.0 reflectance reading [26]. Therefore, higher photovolt reflectance readings are associated with lighter fry color. After fry color determination, the presence or absence of sugar end defect was recorded for each plank. A plank was considered to have a sugar end defect if a predominant color of number 3 or darker, when compared with the USDA Munsell Color Chart for French fried potatoes, was seen on any 2 sides extending $13 \mathrm{~mm}$ or more from the end of the fried plank.

For chipping potatoes at each sampling point, tubers were cut in half lengthwise. A $1 \mathrm{~mm}$ thick slice through the stolon attachment point was removed from one half tuber using a customized cutter and fried in vegetable oil at $185^{\circ} \mathrm{C}$ for $2 \mathrm{~min} 10 \mathrm{~s}$ or until bubbling ceased. Fried chips were crushed for color analysis indicated by Hunter L-values using a D25LT colorimeter (HunterLab, Reston, VA). The Hunter L-values indicate the light vs. dark colors where a low number ( 0 to 50 corresponds to dark) and a high number (51-100 corresponds to light). Each sample consisted of 30 crushed chips, 
three chips from each of ten tubers per replication [27], three replications per variety/wound healing treatment. Samples with Hunter L-values of 55 or higher is acceptable to the potato processing industry.

\subsection{Sugar Extraction and Analysis}

Sucrose and glucose content were determined on the same 10-tuber sample used for the fry color determination by the method of Sowokinos et al. [28] with modifications. The terminal $200 \mathrm{~g}$ on the bud and stem ends, separately, of each tuber were bulked and juiced with an Acme Juicerator (Acme Equipment, Spring Hill, FL) in $50 \mathrm{~mL}$ of sodium-phosphate buffer (pH 7.2). The final volume of the homogenate was brought up to $275 \mathrm{~mL}$ with the same buffer. Glucose and sucrose concentrations were measured using a YSI model 2900 Select Analyzer (Yellow Springs Instrument Inc., Yellow Springs, $\mathrm{OH})$ as per manufacturer's recommendations and expressed on milligram per gram of fresh weight. Procedure for chipping potato sugar analysis was similar except that the central $200 \mathrm{~g}$ on each tuber was processed.

\subsection{Storage Disease Evaluation}

On each sampling date, three replications of 10 tubers from each tote were randomly selected, washed, and cut open from stem end to bud end for a comprehensive disease incidence evaluation of Fusarium dry rot (Fusarium spp.), bacterial soft rot (Pectobacterium spp.) and Pythium leak (Pythium spp.), which are the three major potato storage diseases in Wisconsin. A tuber is considered to have a disease incidence if decay area on the cut surface caused by any of the three pathogens is larger than $5 \%$ [29].

\subsection{Data Analysis}

Due to different sources of potatoes between the two years (donated by commercial fields vs. grown on research plots), analysis of variance (ANOVA) was conducted using the PROC GLM procedure in SAS (version 9.4, SAS Institute Inc., Cary, NC, USA) for each year respectively following a three-factor factorial design, with variety, wound-healing treatment, and storage length as the three main effects, and variation between replications as the error term. Means were separated using Fisher's least significant difference (LSD) at the $\alpha=0.05$ level.

\section{Results}

\subsection{Weather Difference between the Two Seasons}

Figure 2 shows the daily maximum and minimum soil temperatures and precipitation between planting and harvesting in each growing season. It is clear that compared to 2017, 2018 is a much more difficult year with more extreme weather conditions, such as snowy freezing days in late April that delayed planting, very hot days $\left(>30^{\circ} \mathrm{C}\right)$ in late May that had severe impact on plant emergence, big rain events $(>2.5 \mathrm{~cm})$ in mid-June that caused a high percentage of nitrogen fertilizer applied at tuber initiation in early June to leach out, and a series of high-volume rainfalls $(>2.5 \mathrm{~cm})$ in late August that led to saturated unharvestable soils, enlarged lenticels associated with appearance and disease issues, and tuber quality defects causing economic loss. 


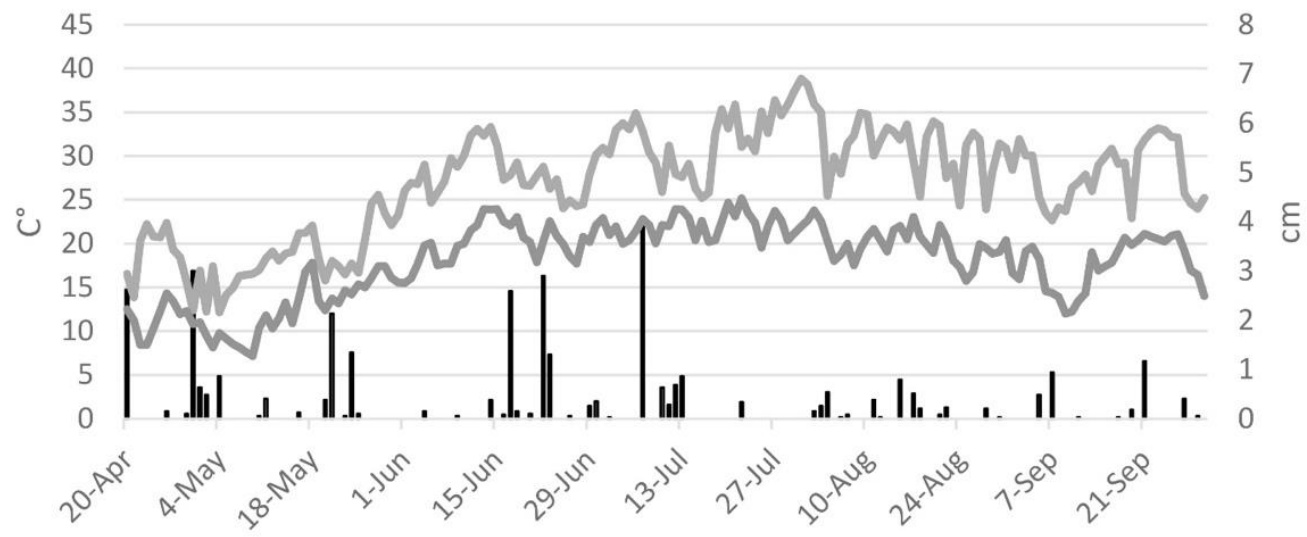

b

\section{Weather}

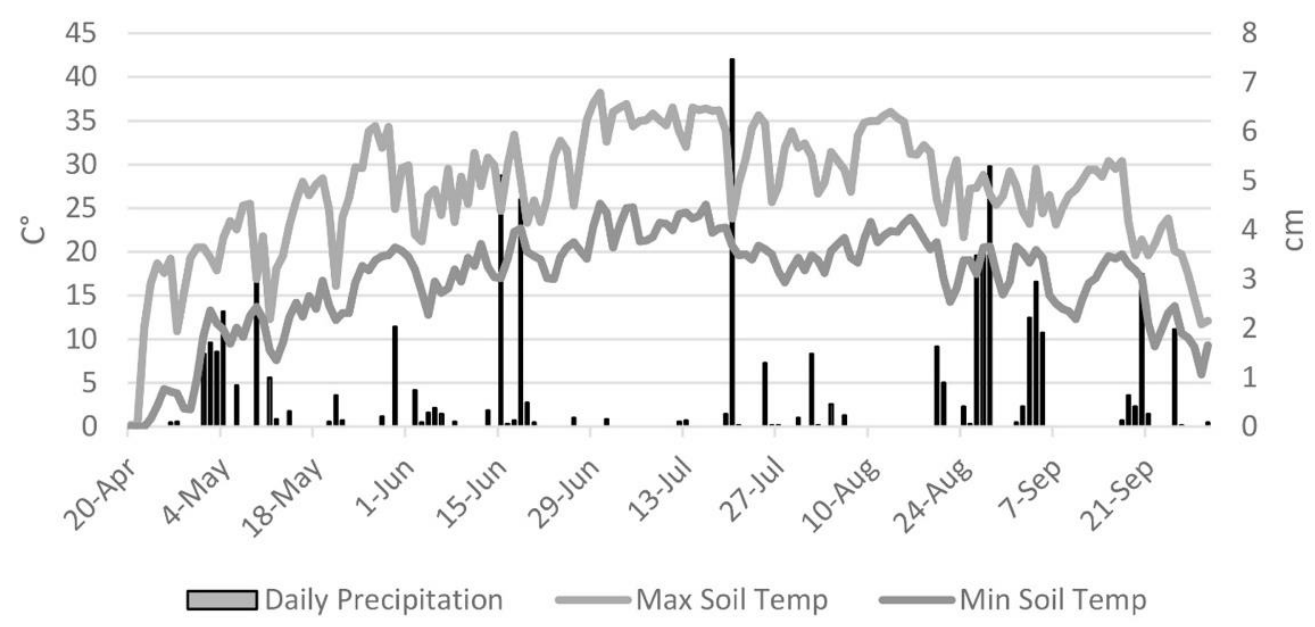

Figure 2. Daily maximum and minimum soil temperatures and precipitation between planting and harvesting in 2017 (a) and 2018 (b).

\subsection{Total Weight Loss}

In 2017 across the treatments, Snowden (12.0\%) had the highest total weight loss compared to the other two varieties (RB 6.9\% and Hodag 6.6\%, $p<0.0001$ ) during the 8 months of storage. Across the three varieties, total weight loss under treatment $1(10.2 \%)$ was significantly higher than under treatment 2 (8\%) and 3 (7.3\%). Hodag and Russet Burbank showed significantly higher weight loss under treatment 1 than the other two treatments, but the difference was not significant on Snowden. For Snowden, total weight loss over the 8-month storage period was always higher than $11 \%$, no matter what wound-healing conditions the tubers were under (Figure 3a). 
a. 2017

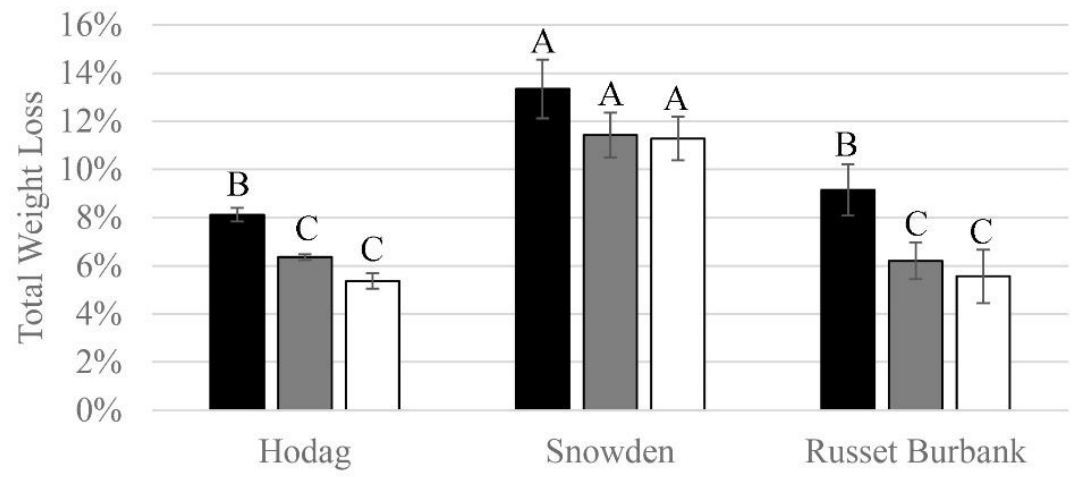

b. 2018

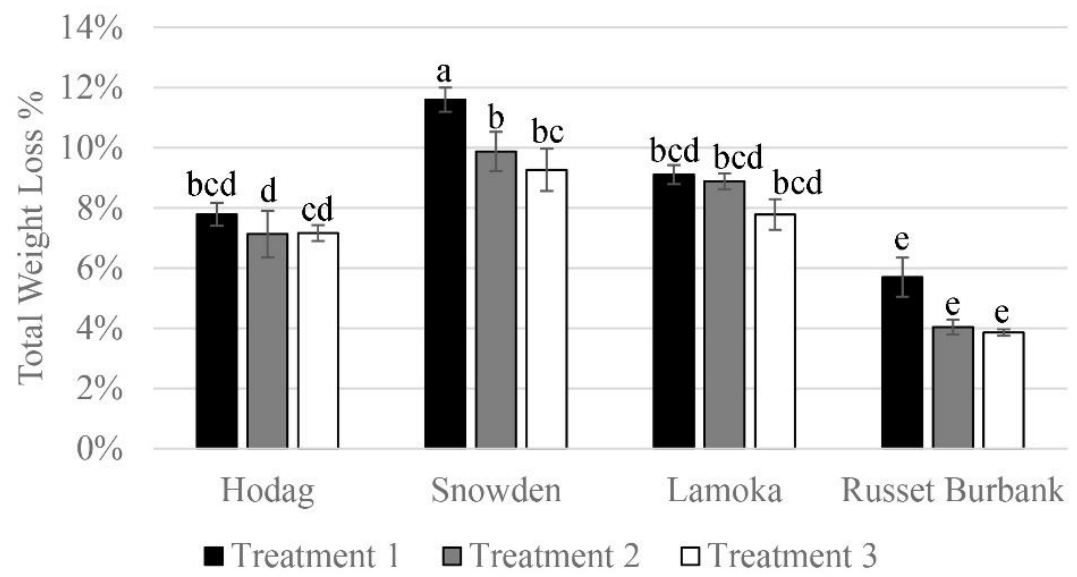

Figure 3. Total weight loss (\%) of different varieties under the three wound-healing treatments in 2017 (a) and 2018 (b). In each figure, bars indicated with different letters are significantly different at $\alpha=0.05$ among different treatments and varieties.

Over the treatments in 2018, Snowden (10.3\%) still showed the highest total weight loss relative to the other varieties (Hodag 7.4\%, Lamoka 8.6\%, and RB 4.5\%, $p<0.0001$ ) during the entire storage season. Unlike 2017, across the four varieties there was not significant difference between total weight loss under different wound-healing treatments, although treatment $1(8.8 \%)$ is greater than treatment 2 $(7.6 \%)$ and treatment $3(7.0 \%)$. Again for Snowden, total weight loss was always higher than the values of other varieties under any of the wound-healing treatments, and its total weight loss under treatment 1 was the highest $(p<0.05$, Figure $3 b)$. Treatment 3 was associated with the lowest total weight loss for all varieties in both years except Hodag in 2018 (Figure 3b).

\subsection{Monthly Weight Loss}

ANOVA results showed that in both years all the main effects, two-way and three-way interactions except variety $\times$ treatment interaction on monthly weight loss were significant at $\alpha=0.05$ (Table 1 ). In 2017 for Hodag, monthly weight loss under treatment 1 had always been higher than weight loss under the other two treatments over the eight-month storage time (Figure 4a). The same trends can be seen on Snowden and Russet Burbank (Figure $4 b, c)$. For all three varieties under treatment 1 , they lost more than $50 \%$ of their weight during the first three months of storage, and these trends under treatment 2 and 3 were not as apparent (Figure 4). Overall, cumulative weight loss of all varieties under treatment 1 were consistently higher than under treatment 2 and 3 (Figure 4). 
Table 1. Analysis of variance (ANOVA) table for monthly weight loss.

\begin{tabular}{ccc}
\hline SOURCE OF VARIATION & \multicolumn{2}{c}{$p$-VALUE } \\
\cline { 2 - 3 } & $\mathbf{2 0 1 7}$ & $\mathbf{2 0 1 8}$ \\
\hline VARIETY & $<0.0001^{* * * *}$ & $<0.0001^{* * * *}$ \\
TREATMENT & $<0.0001^{* * * *}$ & $0.05^{*}$ \\
VARIETY $\times$ TREATMENT & $0.4004^{* * *}$ & 0.4363 \\
STORAGE LENGTH & $<0.0001^{* * * *}$ & $<0.0001^{* * * *}$ \\
VARIETY $\times$ STORAGE LENGTH & $0.0002^{* * *}$ & $0.0166^{*}$ \\
TREATMENT $\times$ STORAGE LENGTH & $<0.0001^{* * * *}$ & $<0.0001^{* * * *}$ \\
VARIETY $\times$ TREATMENT $\times$ STORAGE LENGTH & $0.0071^{* *}$ & $0.0328^{*}$ \\
\hline
\end{tabular}

${ }^{*} p$-value $<0.051,{ }^{* *} p$-value $<0.01,{ }^{* * *} p$-value $<0.001,{ }^{* * * *} p$-value $<0.0001$.

a.

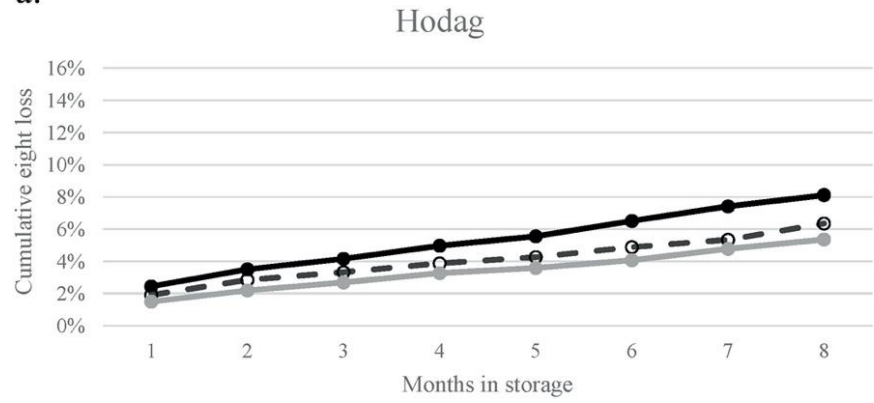

b.

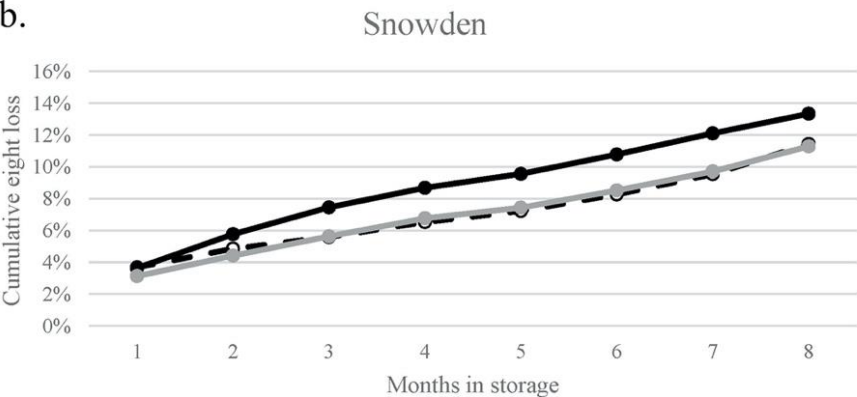

c.

Russet Burbank

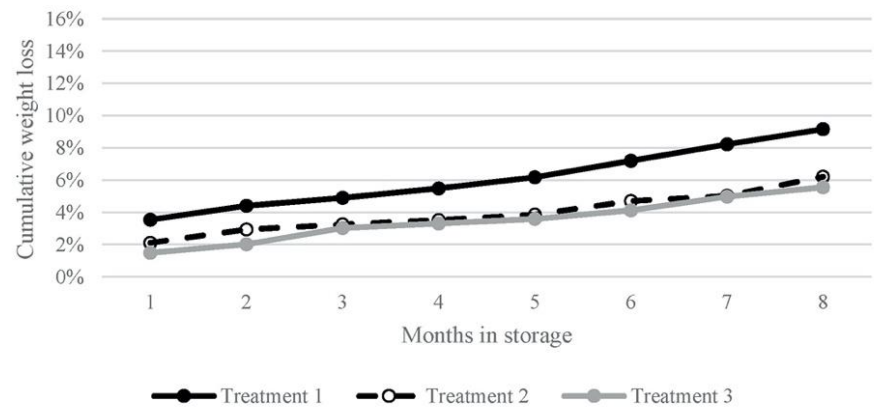

Figure 4. Cumulative monthly weight loss \% of Hodag (a), Snowden (b), and Russet Burbank (c) under the three wound healing treatments in 2017. Least significant difference (LSD, $\alpha=0.05$ ) between each monthly weight loss measurement is $0.5 \%$ among varieties and treatments.

In 2018, weigh loss during the first month under treatment 1 was significantly higher than under the other two treatments for Hodag (Figure 5a), Lamoka (Figure 5c) and RB (Figure 5d), and significantly higher than under treatment 3 for Snowden (Figure $5 b$ ). During the last two months of storage, weight loss under treatment 1 was higher than the other treatments for Snowden and Russet $(p<0.05)$ as well as Hodag and Lamoka (not significant). For all four varieties in 2018, there was a trend 
of increasing monthly weight loss during the last two months of storage (Figure 5). For each variety in 2018, weight loss under treatment 1 during the first three months accounted for at least $50 \%$ of the total weight loss over the entire storage season (Figure 5). It is observed again that cumulative weight loss of each of the four varieties under treatment 1 was always higher than the other two treatments over the storage season.

a.

Hodag

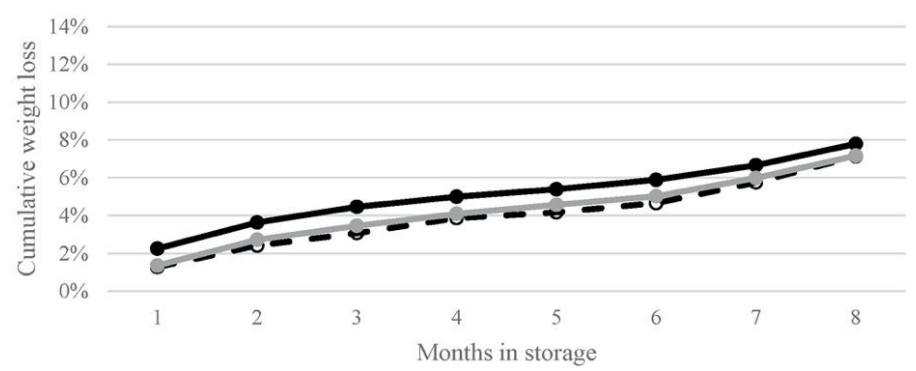

b.

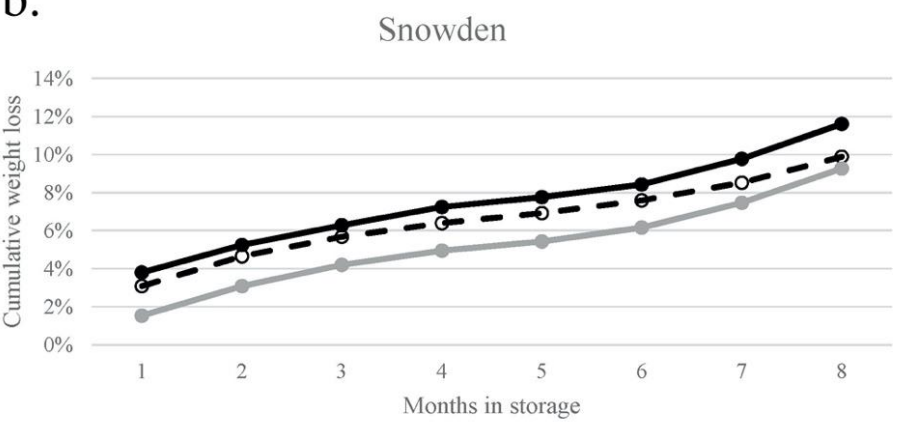

c.

Lamoka

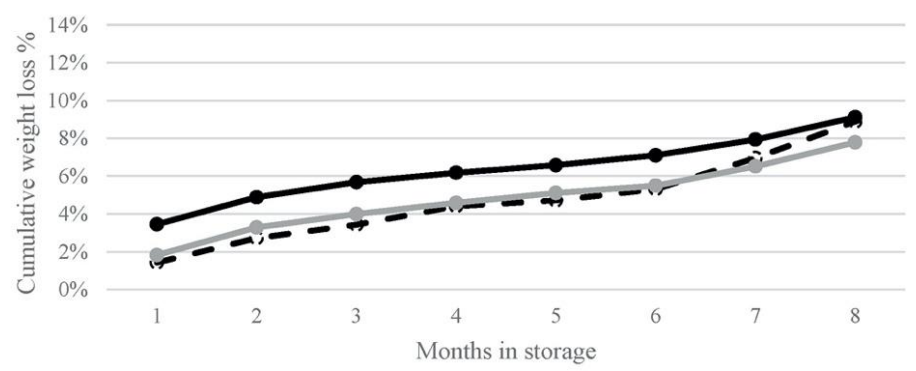

d.

Russet Burbank

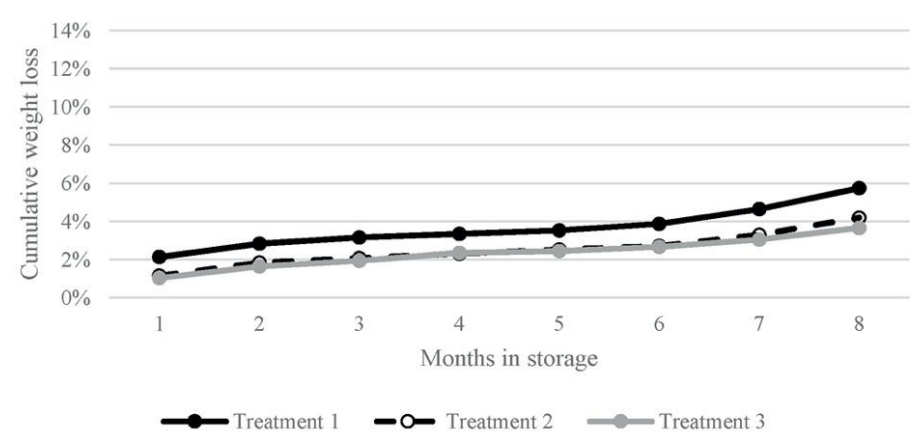

Figure 5. Cumulative monthly weight loss \% of Hodag (a), Snowden (b), Lamoka (c) and Russet Burbank (d) under the three wound healing treatments in 2018. LSD $(\alpha=0.05)$ between each monthly weight loss measurement is $0.7 \%$ among varieties and treatments. 


\subsection{Glucose Content of the Chipping Varieties}

ANOVA shows that in 2017, all the main effects and their two-way and three-way interactions were highly significant $(p<0.001$, Table 2$)$, however in 2018, only the effects of variety, storage length and their two-way interactions were significant (Table 2). In 2017 for Hodag, not much difference can be seen on glucose content between different wound-healing conditions. Hodag is featured with its consistently low glucose levels during long-term post-harvest storage (Figure 6a). For Snowden, no difference can be observed until the seventh month in storage, and tubers under treatment 1 showed significantly higher levels of glucose than under the other treatments, however, under treatment 3 glucose stayed below $0.35 \mathrm{mg} / \mathrm{g}$ FW throughout the storage season (Figure 6b). In 2018, significant interaction between variety and storage length was shown in Figure 7. For Snowden in particular, there was a steep jump of glucose during the last two storage months.

Table 2. ANOVA table for glucose content of chipping varieties.

\begin{tabular}{ccc}
\hline SOURCE OF VARIATION & \multicolumn{2}{c}{$p$-VALUE } \\
\cline { 2 - 3 } & $\mathbf{2 0 1 7}$ & $\mathbf{2 0 1 8}$ \\
\hline VARIETY & $<0.0001^{* * * *}$ & $<0.0001^{* * * *}$ \\
TREATMENT & $<0.0001^{* * * *}$ & 0.1145 \\
VARIETY $\times$ TREATMENT & $0.0004^{* * *}$ & 0.2015 \\
STORAGE LENGTH & $<0.0001^{* * * *}$ & $<0.0001^{* * * *}$ \\
VARIETY $\times$ STORAGE LENGTH & $<0.0001^{* * * *}$ & $<0.0001^{* * * *}$ \\
TREATMENT $\times$ STORAGE LENGTH & $<0.0001^{* * * *}$ & 0.5071 \\
VARIETY $\times$ TREATMENT $\times$ STORAGE LENGTH & $0.0001^{* * *}$ & 0.9798 \\
\hline
\end{tabular}

${ }^{*} p$-value $<0.05,{ }^{* *} p$-value $<0.01,{ }^{* * *} p$-value $<0.001,{ }^{* * * *} p$-value $<0.0001$.

a

Hodag

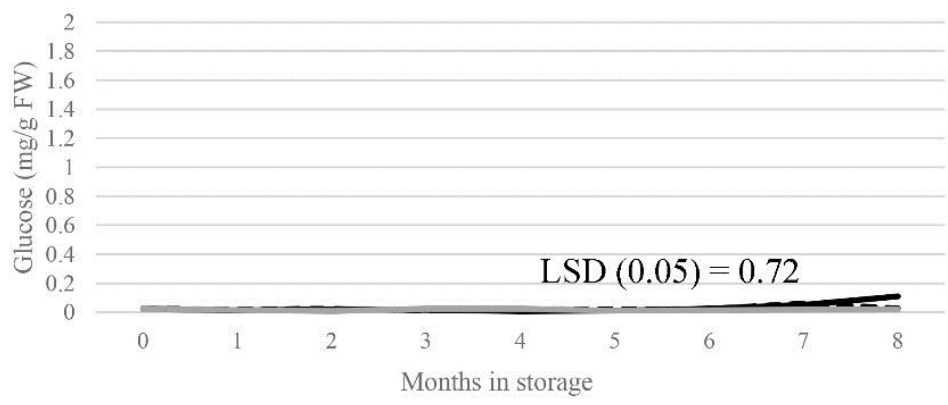

b

\section{Snowden}

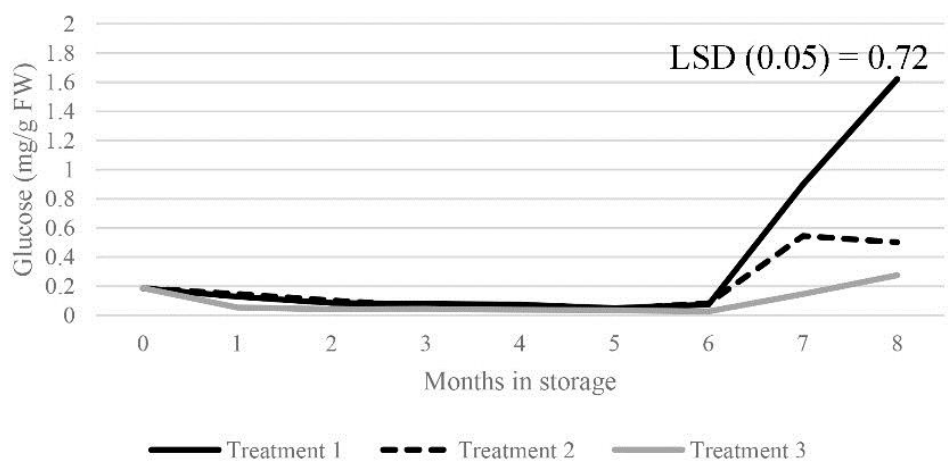

Figure 6. Glucose content (mg/g Fresh Weight) of Hodag (a), Snowden (b) under the three wound healing treatments in 2017. 


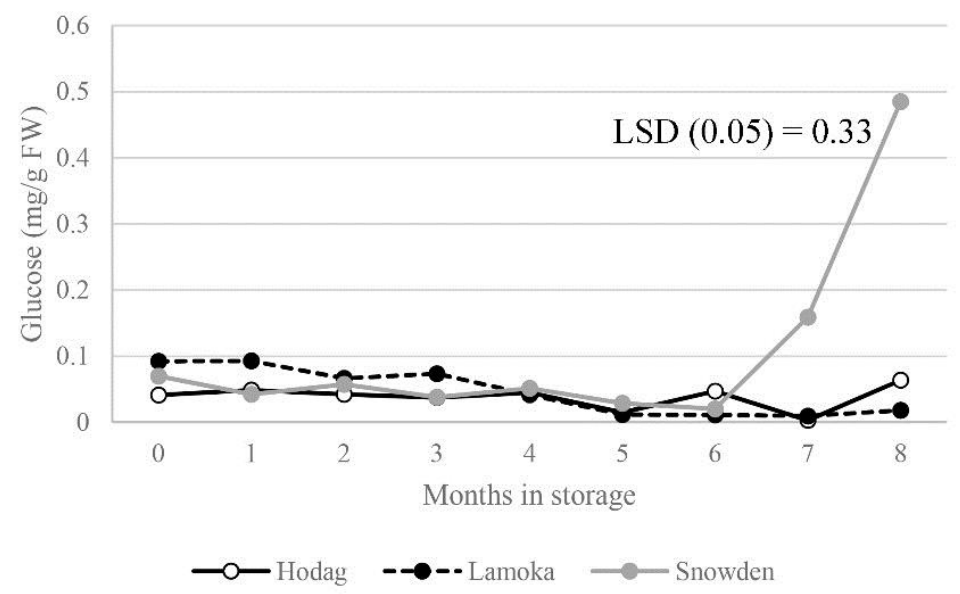

Figure 7. Glucose content (mg/g fresh weight) of three chipping varieties across the three wound healing treatments in 2018.

\subsection{Glucose Content of Russet Burbank}

In 2017, neither wound-healing treatment nor storage length had significant impacts on the stem-end and bud-end glucose content of Russet Burbank tubers. Whereas in 2018, the two main effects and their interactions were significant on the glucose content of both ends $(p<0.05)$. A big difference of stem-end glucose between treatment 1 and the other two treatments was observed during the last four months of storage ( $p<0.05$, Figure $8 a)$, suggesting potential fry quality issues. A significant difference of bud-end glucose between treatment 1 and the other two treatments was noticed in the 2nd and 4th storage month, but the number under treatment 3 was significantly higher than under treatment 1 during the 7 th month of storage $(p<0.05$, Figure $8 b)$. At the other sampling points, no difference of bud-end glucose was captured between the three wound-healing treatments (Figure 8b).

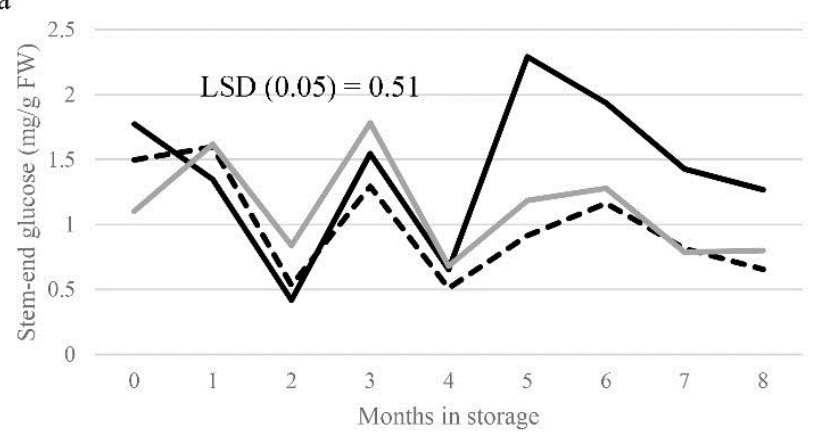

b

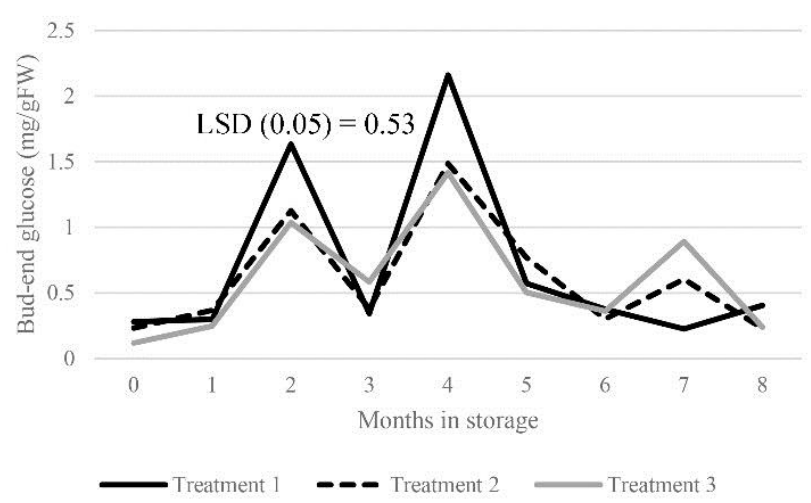

Figure 8. Stem-end glucose content (mg/g Fresh Weight, a) and bud-end glucose content (b) of Russet Burbank under the three wound-healing treatments in 2018. 


\subsection{Fry Color of the Chipping Varieties}

Consistent with ANOVA results from the glucose content analysis, Hunter L-values, which are indicators of chip fry color and need to be above 55 by industry standards, were significantly affected by all of the three main effects, their two-way and three-way interactions in 2017, whereas in 2018 only variety, storage length and their interaction had p-values lower than 0.05 (Table 3).

Table 3. ANOVA table for Hunter L-values that indicate fry color of the chipping varieties.

\begin{tabular}{ccc}
\hline SOURCE OF VARIATION & \multicolumn{2}{c}{$p$-VALUE } \\
\cline { 2 - 3 } & $\mathbf{2 0 1 7}$ & $\mathbf{2 0 1 8}$ \\
\hline VARIETY & $<0.0001^{* * * *}$ & $<0.0001^{* * * *}$ \\
TREATMENT & $<0.0001^{* * * *}$ & 0.4229 \\
VARIETY $\times$ TREATMENT & $0.0014^{* *}$ & 0.1481 \\
STORAGE LENGTH & $<0.0001^{* * * *}$ & $<0.0001^{* * * *}$ \\
VARIETY $\times$ STORAGE LENGTH & $<0.0001^{* * * *}$ & $<0.0001^{* * * *}$ \\
TREATMENT $\times$ STORAGE LENGTH & $0.0309^{*}$ & 0.6649 \\
VARIETY $\times$ TREATMENT $\times$ STORAGE LENGTH & $0.0086^{* *}$ & 0.5582 \\
\hline
\end{tabular}

${ }^{*} p$-value $<0.05,{ }^{* *} p$-value $<0.01,{ }^{* * *} p$-value $<0.001,{ }^{* * * *} p$-value $<0.0001$.

Figure 9a shows that Hodag always had Hunter L-values beyond 55 throughout the 8-month storage period, no matter what wound-healing conditions the tubers went through, and this again demonstrated Hodag's premium long-term storability. However for Snowden, Hunter L-values under all treatments stayed high until the 6th month in storage, and steeply dropped below 50 under treatment 1 in the 7th month (Figure 9b). The numbers under treatment 2 decreased down to 51 in the 8th month, and numbers under treatment 3 stayed high all the time (Figure 9b). This together with the glucose content results suggest that Treatment 3 was helpful to maintain good fry quality for Snowden all season long.

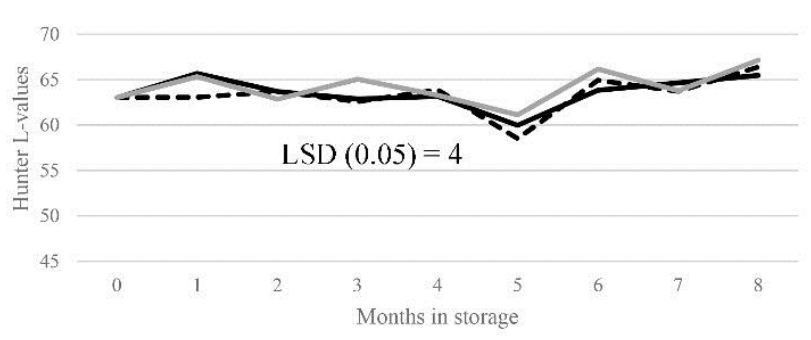

b

Snowden

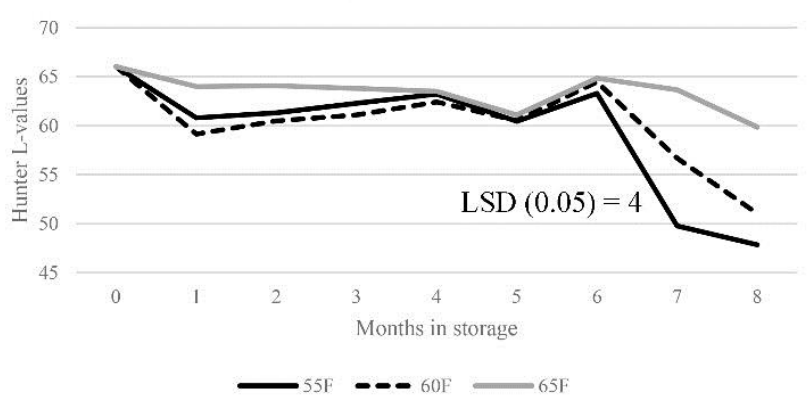

Figure 9. Hunter L-values of Hodag (a) and Snowden (b) under the three wound healing treatments in 2017. 


\subsection{Fry Color and Sugar End Defect of French Fries Made from Russet Burbank}

In both years, stem-end and bud-end fry color was only significantly impacted by the main effect of wound-healing treatment $(p<0.05)$. Treatment 3 led to significantly higher photovolt readings, suggesting lighter fry color compared to treatment 1 (Table 4 ). The incidence of sugar end defect was only significantly influenced by treatment in $2018(p<0.05)$, with numbers under treatment $1>$ treatment $2>$ treatment 3 . No difference of treatments was observed in 2017 (Table 4).

Table 4. Photovolt readings at the stem end and sugar end defect incidence of French fries processed from Russet Burbank potatoes, under different wound healing conditions in each year. (n.s. not significant, numbers followed by different letters are significantly different at $\alpha=0.05$ ).

\begin{tabular}{ccccc}
\hline Wound Healing & \multicolumn{2}{c}{ Stem-End Fry Color } & \multicolumn{2}{c}{ Sugar End Defect Incidence } \\
\cline { 2 - 5 } Conditions & $\mathbf{2 0 1 7}$ & $\mathbf{2 0 1 8}$ & $\mathbf{2 0 1 7}$ & $\mathbf{2 0 1 8}$ \\
\hline Treatment $\mathbf{1}$ & $27 \mathrm{~B}$ & $25 \mathrm{c}$ & $3 \%$ n.s. & $25 \% \mathrm{a}$ \\
\hline Treatment $\mathbf{2}$ & $33 \mathrm{AB}$ & $30 \mathrm{~b}$ & $2 \%$ n.s. & $17 \% \mathrm{~b}$ \\
\hline Treatment $\mathbf{3}$ & $35 \mathrm{~A}$ & $37 \mathrm{a}$ & $3 \%$ n.s. & $9 \% \mathrm{c}$ \\
\hline
\end{tabular}

\subsection{Disease Evaluation}

No difference of disease incidence was captured between the wound-healing treatments for any variety in any given year. Disease decay generally was less than $5 \%$ in all totes throughout the 8-month storage season.

\section{Discussion}

\subsection{Warmer Wound-Healing Temperature Resulted in Less Weight Loss, Particularly during the Early Storage} Season

In general, higher temperatures at 15.6 and $18.3^{\circ} \mathrm{C}$ favored the wound-healing process by causing less total weight loss in all tested varieties during the 8-month storage. This could be a result of faster suberization under 15.6 and $18.3^{\circ} \mathrm{C}$, as warmer temperatures enhance suberization, whereas cooler temperatures suppress suberin synthesis and the formation of wound periderm [30]. Since relative humidity and airflow were controlled to be the same between different treatments in this study, temperature difference turns out to be the only driver for different weight loss of the three wound-healing treatments, regardless of the variety.

Potato weight loss is primarily caused by tuber transpiration and respiration during storage. Transpiration contributes to more than $90 \%$ of total weight loss, and is mostly caused by diffusion of water vapor from the tuber skin to the surrounding air due to the difference in water vapor pressure within the cells of the tuber skin and the air, called water vapor pressure deficit [31,32]. The higher the ambient air temperature, the more water loss from the tuber. Respiration, responsible for converting starch and sugars into carbon dioxide and water in stored potatoes [33], accounts for $5 \%$ to $10 \%$ of total tuber weight loss [34]. Respiration rate is increased under higher storage temperature [35-37]. In this study, although higher temperatures at 15.6 and $18.3^{\circ} \mathrm{C}$ could promote both transpiration and respiration during the wound-healing stage, their influences could be offset by higher rates of suberization, and therefore the net result is less tuber weight loss over the entire storage season, particularly under treatment 3.

The findings of this study were consistent with previous research that $>50 \%$ of the total weight loss occurred during the first 2 months of storage because potatoes in the early part of the storage season have higher transpiration and respiration rates [14,38,39], and the trend is especially clear under treatment 1 (Figures 4 and 5). After this period, weight loss stayed below $2 \%$ per month.

Another factor that can cause potato weight loss is sprout growth during storage [32]. Burton [40] estimated that respiration of potatoes increases by $50 \%$ if sprouts reach $1 \%$ of tuber weight. It has been 
found that the sprout growth equivalent to $1 \%$ increase in the tuber surface area can lead to doubling of the moisture loss from the tubers [41]. In the second year of our study (2018), the start of sprouts growth (peeping) was observed from the sixth month of storage, which might be the reason for slight to medium increase of weight loss of all four varieties during the last stage of storage (Figure 5).

\subsection{Snowden Tends to Lose More Weight Compared to Other Varieties during Storage}

A clear varietal difference was shown by this two-year study that Snowden loses the most weight among the four tested varieties. Potato tuber weight loss can be influenced by many factors, such as the type of tuber skins (russeting vs. non-russeting), tuber skin maturity at harvest, the rate of transpiration and respiration during storage, the rate of sprouting, and storage conditions. It is not clear what caused Snowden to lose the most weight compared to other varieties. Being on top of the storage pile that exposed the tubers to more airflow could be one reason, and researchers who conducted the storage study in macro totes at HPSRF have indicated similar findings previously [42]. However, Peck [14] found no significant difference of weight loss in commercially stored potatoes placed on top of the pile compared to those buried within the pile. The russeted skin of Russet Burbank could be responsible for its lower weight loss compared to Snowden (Figure 3), due to the thicker periderm and thus a better barrier against moisture loss. Future research is needed to investigate how skin maturity affects Snowden's weight loss, as Butchbaker et al. [33] found that later-maturing varieties showed greater total weight loss than earlier-maturing ones. Respiration rate over the course of the storage season should also be assessed in future studies in order to identify the cause for Snowden's high weight loss potential.

\subsection{Senescent Sweetening of Snowden was Ameliorated under Higher Wound-Healing Temperature}

Potato tubers during the late stage of storage will undergo a developmentally controlled, age-dependent shift in metabolism that results in an accumulation of sugars such as sucrose and glucose, a process that is called senescent sweetening [43]. The most widely accepted hypothesis for the mechanism of senescent sweetening is that tuber tissue senescence after a certain period of time in storage including the breakdown of the cell membrane, can facilitate enzyme access to starch granules and speed up starch conversion to sugars [44], which then results in unacceptable darkening of finished fries in a chemical process called the Maillard reaction [45]. Varieties that are most susceptible to senescent sweetening tend to have shorter dormancy. Growing conditions including early planting and water and heat stresses, as well as storage conditions such as higher storage temperature can all affect the onset of senescent sweetening [44].

In this study, Snowden underwent senescent sweetening during the last two months of storage in both years; particularly in 2017, Snowden under treatment 1 showed the worst senescent sweetening (Figures $6 \mathrm{~b}$ and 7). This is likely due to Snowden's relatively shorter dormancy compared to the other two chipping varieties and Russet Burbank, its growing conditions in the summer and its maturity when harvested on the commercial field in 2017. The finding that Treatment 1 , the lowest wound-healing temperature, resulted in the most severe senescent sweetening in 2017 does not agree with previous research findings [44]. Lower wound-healing temperature should slow down the process of tuber physiological aging, leading to less senescent sweetening. Further research needs to be conducted to explore the reason. Comparatively, both Hodag and Lamoka are characterized by their long dormancy, absence of senescent sweetening in the late storage stage, and premium fry quality for long-term storage (Figures 6a and 7)

\subsection{Fry Quality of Russet Burbank Can Be Improved by Increased Wound-Healing Temperature}

For Russet Burbank, wound healing at warmer temperatures resulted in lower stem-end glucose (Figure 8) and thus lighter fry color compared to the standard treatment under a cooler wound-healing temperature (Table 4). This finding is consistent with [14] and [46]. Glucose is limiting for the Maillard reaction, and fry color is proportional to glucose concentration in tubers at the time of processing [46]. 
According to the USDA standards, if the fry color is darker than a certain threshold, the French fries are culled as sugar-end defected, which can lead to rejection and economic loss at the processing plant [46]. Glucose is broken down from sucrose. Higher wound-healing temperature can accelerate tuber respiration, a process that consumes sucrose in the tuber during the early storage stage [47]. RB's stem-end sucrose level is significantly lower under treatment 3, the highest wound-healing temperature, after the wound-healing period concluded in this study in both years (data not shown). Tuber maturity and size profile at harvest can also affect tuber sugar level and frying quality during storage [48].

However, in this study since all tubers were produced from the same commercial field in 2017, the same research plot in 2018, and only the 171 to $284 \mathrm{~g}$ healthy tubers (marketable size) were retained for sugar analysis, the better frying quality of RB under treatment 3 should be most likely caused by warmer wound-healing temperatures.

\subsection{If Tubers Were Harvested Healthy, Higher Wound-Healing Temperature Will Not Cause Disease Issues during Storage}

One of the biggest challenges of increasing wound-healing temperature is the consequence of disease development because most rot organisms spread much faster at warm temperatures $[19,45,46]$. It is found in this study that if tubers were in a good condition out of field, even high wound-healing temperature at $18.3{ }^{\circ} \mathrm{C}$ only resulted in lower than $3 \%$ of rot decay during the 8 -month storage season.

\section{Conclusions}

In this study, we evaluated the effects of higher wound-healing temperatures at $15.6{ }^{\circ} \mathrm{C}$ and $18.3^{\circ} \mathrm{C}$ compared to the U.S. potato industry standard wound-healing temperature, which is at $12.8^{\circ} \mathrm{C}$. Although the difference in benefits between $15.6^{\circ} \mathrm{C}$ and $18.3^{\circ} \mathrm{C}$ is not significant, we have found that overall higher wound-healing temperatures are associated with benefits such as:

1. Less weight loss particularly during the first three months of storage;

2. Can potentially mitigate senescent sweetening for certain varieties like Snowden during the last two months of storage;

3. Can improve fry quality of Russet Burbank with lower glucose content and lighter fry color;

4. Will not lead to significant disease spread if healthy tubers are harvested and stored.

However, the macro plastic tote used for storage in this study can only hold $450 \mathrm{~kg}$ of potatoes and is different from the U.S. commercial storage facility, which can hold at least 1 million $\mathrm{kg}$ of potatoes. Therefore future study is needed to evaluate if findings from this study hold true in a commercial environment.

Author Contributions: Conceptualization: Y.W.; Funding acquisition: Y.W.; Methodology: Y.W. and M.R.N.; Data curation and formal analysis: M.R.N. and T.W.C.; Original draft preparation, Y.W.; Writing, review and editing: Y.W., M.R.N., T.W.C. All authors have read and agreed to the published version of the manuscript.

Funding: This research was supported by an industry research grant entitled Effects of higher temperature and shorter duration of wound healing on potato long-term storability. The grant was provided by the Wisconsin Potato Industry Board.

Acknowledgments: The authors thank Troy Fishler, Amber Gotch and other support staff at the UW Hancock Potato Storage Research Facility for loading the macro totes, managing the storage conditions, and conducting sugar analysis and fry color analysis. The authors sincerely thank the commercial growers for donating potatoes for this project in 2017. The authors thank Paul Sytsma and the field crew at the UW Hancock Agricultural Research Station for providing field management assistance in 2018. The authors also thank the Wisconsin Potato and Vegetable Growers Association for providing funds to cover the research and the publication costs.

Conflicts of Interest: There are no conflicts of interest for this research.

\section{References}

1. Ware, G.W.; Mccollum, J.P. Producing Vegetable Crops, 1st ed.; Interstate Printers: Danville, IL, USA, 1968.

2. Kleinkopf, G.E. Early storage season. Am. Potato J. 1995, 72, 449-462. [CrossRef] 
3. Knowles, N.R.; Iritani, W.M.; Weller, L.D.; Gross, D.C. Susceptibility of potatoes to bacterial rot and weight loss as a function of wound-healing interval and temperature. Am. Potato J. 1982, 59, 515-522. [CrossRef]

4. Barel, G.; Ginzberg, I. Potato skin proteome is enriched with plant defence components. J. Exp. Bot. 2008, 59, 3347-3357. [CrossRef] [PubMed]

5. Olsen, N.; Thornton, M.K.; Nolte, P. Wound Healing: Potatoes Natural Band-Aid. Idaho Potatoes. Available online: https://idahopotato.com/uploads/media/wound-healing.pdf (accessed on 15 May 2019).

6. Lipetz, J. Wound-healing in higher plants. Int. Rev. Cytol. 1970, 27, 1-28.

7. Artschwager, E. Wound periderm formation in the potato as affected by temperature. J. Agric. Res. 1927, 35, 995-1000.

8. Dastmalchi, K.; Cai, Q.; Zhou, K.; Huang, W.; Serra, O.; Stark, R.E. Solving the Jigsaw puzzle of wound-healing potato cultivars: Metabolite profiling and antioxidant activity of polar extracts. J. Agric. Food Chem. 2014, 62, 7963-7975. [CrossRef]

9. Neubauer, J.D.; Lulai, E.C.; Thompson, A.L.; Suttle, J.C.; Bolton, M.D. Wounding coordinately induces cell wall protein, cell cycle and pectin methyl esterase genes involved in tuber closing layer and wound periderm development. J. Plant. Physiol. 2012, 169, 586-595. [CrossRef]

10. Lulai, E.C.; Campbell, L.G.; Fugate, K.K.; McCue, K.F. Biological differences that distinguish the 2 major stages of wound healing in potato tubers. Plant Signal. Behavior 2016, 11, e1256531. [CrossRef]

11. Graca, J. Suberin: The biopolyester at the frontier of plants. Front. Chem. 2015, 62, 1-11.

12. Hawkins, S.; Boudet, A. Wound-induced lignin and suberin deposition in a woody angiosperm (Eucalyptus gunnii Hook.): Histochemistry of early changes in young plants. Protoplasma 1996, 191, 96-104. [CrossRef]

13. Lulai, E.C. Skin-set, wound healing, and related defects. In Potato Biology and Biotechnology: Advances and Perspectives, 1st ed.; Vreugdenhil, D., Ed.; Elsevier: Amsterdam, The Netherlands, 2007; pp. 471-497.

14. Peck, S.M. Integrating Cultivar, Temperature and Quality into Early Storage Management Decisions for Wound Healing in Potatoes (Solanum tuberosum L.). Ph.D. Thesis, University of Idaho, Moscow, ID, USA, 2015.

15. Priestly, J.H.; Woffenden, L.M. Physiological studies of plant anatomy. V. Causal. New Phytol. 1922, 21, 253-268.

16. Morris, S.C.; Forbes-Smith, M.R.; Scriven, F.M. Determination of optimum conditions for suberization, wound periderm formation, cellular desiccation and pathogen resistance in wounded Solanum tuberosum tubers. Physiol. Mol. Plant. Pathol. 1989, 35, 177-190. [CrossRef]

17. Wigginton, M.J. Diffusion of oxygen through lenticels in potato tuber. Potato Res. 1973, 16, 85-87. [CrossRef]

18. Thomas, P. Wound-induced suberization and periderm development in potato tubers as affected by temperature and gamma irradiation. Potato Res. 1982, 25, 155-164. [CrossRef]

19. Kleinkopf, G.E.; Olsen, N. Storage management. In Potato Production Systems; Stark, J.C., Love, S.L., Eds.; University of Idaho Extension: Moscow, ID, USA, 2003; pp. 363-382.

20. Daniels-Lake, B.; Prange, R.K.; Walsh, J.; Hiltz, K.; Bishop, S.; Munro-Pennell, K.D. Effects of simulated harvest injury and relative humidity during the first week post-harvest on potato (Solanum tuberosum L.) tuber weight loss during subsequent storage. J. Hortic. Sci. Biotechnol. 2014, 89, 167-172. [CrossRef]

21. Pringle, R.T.; Bishop, C.F.H.; Clayton, R.C. Potatoes Postharvest; CABI: Wallingford, UK, 2009.

22. Voss, R.E.; Baghott, K.G.; Timm, H. Proper Environment for Potato Storage. Available online: https: //vric.ucdavis.edu/pdf/POTATOES/potato_storage.pdf (accessed on 20 September 2019).

23. Ellis, G.D.; Knowles, L.O.; Knowles, N.R. Respiratory and low-temperature sweetening responses of fresh-cut potato (Solanum tuberosum L.) tubers to low oxygen. Postharvest Biol. Technol. 2019, 156, 110937. [CrossRef]

24. Colquhoun, J.B.; Chapman, S.A.; Gevens, A.J.; Groves, R.L.; Heider, D.J.; Jensen, B.M.; Nice, G.R.W.; Ruark, M.D. Commercial Vegetable Production in Wisconsin-2019, SKU A3422; University of Wisconsin-Madison Extension: Madison, WI, USA, 2019.

25. Kincaid, D.C.; Westermann, D.T.; Trout, T.J. Irrigation and soil temperature effects on Russet Burbank quality. Am. Potato J. 1993, 70, 711-723. [CrossRef]

26. Thornton, M.; Buhrig, W.; Olsen, N. The relationship between soil temperature and sugar ends in potato. Potato Res. 2010, 53, 289-296. [CrossRef]

27. Wiberley-Bradford, A.E.; Bethke, P.C. Rate of cooling alters chip color, sugar contents, and gene expression profiles in stored potato tubers. Am. J. Potato Res. 2017, 94, 534-543. [CrossRef]

28. Sowokinos, J.R.; Shock, C.C.; Stieber, T.D.; Eldredge, E.P. Compositional and enzymatic changes associated with the sugar-end defect in Russet Burbank potatoes. Am. J. Potato Res. 2000, 77, 47-56. [CrossRef] 
29. Brandt, T.L.; Olsen, N.; Novy, R.G.; Whitworth, J.L.; Wang, Y. Storage Management of Payette Russet 2016; Extension Current Information Series 1220; Univeresity of Idaho: Moscow, ID, USA, 2016.

30. Thomson, N.; Evert, R.F.; Kelman, A. Wound healing in whole potato tubers: A cytochemical, fluorescence, and ultrastructural analysis of cut and bruise wounds. Can. J. Bot. 1995, 73, 1436-1450. [CrossRef]

31. Lutman, B.F. Carbon dioxide formation by clean and scabby potatoes. J. Agric. Res. 1934, 12, 1135-1144.

32. Mehta, A.; Kaul, H.N. Effect of sprout inhibitors on potato tubers (Solanum tuberosum L.) stored at ambient or reduced temperatures. Potato Res. 1991, 34, 443-450. [CrossRef]

33. Butchbaker, A.F.; Promersberger, W.J.; Nelson, D.C. Respiration of Weight Loss of Potatoes During Storage. Available online: https://ibrary.ndsu.edu/ir/bitstream/handle/10365/9798/farm_30_03_05.pdf?sequence=1 (accessed on 20 November 2019).

34. Castleberry, H.C. Development of Methods to Estimate or Reduce Pressure Flattening of Potatoes During Storage. Ph.D. Thesis, Colorado State University, Fort Collins, CO, USA, 2013.

35. Burton, W.G. The Potato. A Survey of its History and of Factors Influencing its Yield, Nutritive Value, Quality and Storage, 2nd ed.; H. Veenman \& Zonen: Wageningen, The Netherlands, 1966.

36. Sparks, W.C. Effect of storage temperature on storage losses of Russet Burbank potatoes. Am. Potato J. 1965, 42, 241-246. [CrossRef]

37. Fennir, M.; Landry, J.A.; Raghavan, V.G.S. Respiration rate of potatoes (Solanum tuberosum L.) measured in a two-bin research scale storage facility, using heat and moisture balance and GC analysis. Can. Biosyst. Eng. 2003, 45, 4.1-4.9.

38. Lommen, W.J.M. Post-harvest characteristics of potato minitubers with different fresh weights and from different harvests. II. Losses during storage. Potato Res. 1993, 36, 265-272. [CrossRef]

39. Thornton, M.K.; Bohl, W.H. Preventing Potato Bruise Damage 1998; Extension Current Information Series 725; University of Idaho: Moscow, ID, USA, 1998.

40. Burton, W.G. Biological and economic aspects of the refrigerated storage of potatoes. Proc. Inst. Refrig. 1955, 51, 168-172.

41. Paul, V.; Ezekiel, R.; Pandey, R. Sprout suppression on potato: Need to look beyond CIPC for more effective and safer alternatives. J. Food Sci. Technol. 2016, 53, 1-18. [CrossRef]

42. Bethke, P.C.; (University of Wisconsin-Madison, Madison, WI, USA). Personal communication, 2019.

43. Wiberley-Bradford, A.E.; Bethke, P.C. Suppression of the vacuolar invertase gene delays senescent sweetening in chipping potatoes. J. Sci. Food Agric. Chem. 2018, 98, 354-360. [CrossRef]

44. Colgan, R.J.; Rees, D.; Briddon, A. Research Review: Senescent Sweetening. Available online: https://potatoes. ahdb.org.uk/sites/default/files/publication_upload/20126\%20Senescent\%20Sweetening\%20R442.pdf (accessed on 20 November 2019).

45. Zommick, D.H.; Knowles, L.O.; Knowles, N.R. Tuber respiratory profiles during low temperature sweetening (LTS) and reconditioning of LTS-resistant and susceptible potato (Solanum tuberosum L.) cultivars. Postharvest Biol. Technol. 2014, 92, 128-138. [CrossRef]

46. Driskill, E.P.J.; Knowles, L.O.; Knowles, N.R. Temperature-induced changes in potato processing quality during storage are modulated by tuber maturity. Am. J. Potato Res. 2007, 85, 367-383. [CrossRef]

47. Bussan, A.J.; Saba, R.P.; Drilias, M.J. Tuber Maturation and Potato Storability: Optimizing Skin Set, Sugars, and Solids, 2009; UW Cooperative Extension Bulletin A3884-02; University of Wisconsin Extension: Madison, WI, USA, 2009.

48. Pritchard, M.K.; Adam, L.R. Preconditioning and storage of chemically immature Russet Burbank and Shepody potatoes. Am. Potato J. 1992, 69, 805-815. [CrossRef]

(C) 2020 by the authors. Licensee MDPI, Basel, Switzerland. This article is an open access article distributed under the terms and conditions of the Creative Commons Attribution (CC BY) license (http://creativecommons.org/licenses/by/4.0/). 